\title{
Gap-junctional communication in mouse cumulus-oocyte complexes: implications for the mechanism of meiotic maturation
}

\author{
R. J. Webb, H. Bains, C. Cruttwell and J. Carroll* \\ Department of Physiology, University College London, Gower Street, \\ London WC1E 6BT, UK
}

The mechanisms underlying the hormonal stimulation of meiotic maturation are not understood. The most prevalent hypothesis is that hormone-induced maturation is stimulated by an increase in the intracellular messengers, cAMP or $\mathrm{Ca}^{2+}$. This study investigated whether $\mathrm{Ca}^{2+}$ transients in somatic cells can lead to $\mathrm{Ca}^{2+}$ transients in the oocyte, and whether hormones that stimulate meiotic maturation of mouse oocytes in vitro and in vivo stimulate an increase in intracellular $\mathrm{Ca}^{2+}$. Of a range of potential agonists of $\mathrm{Ca}^{2+}$ release, ATP and UTP were the only agents that stimulated $\mathrm{Ca}^{2+}$ release in cumulus cells. ATP-induced $\mathrm{Ca}^{2+}$ release is from intracellular stores, as the response is not blocked by chelation of extracellular $\mathrm{Ca}^{2+}$, but is inhibited by the $\mathrm{Ca}^{2+}$ ATPase inhibitor, thapsigargin. ATP and UTP are equipotent, consistent with the receptor being of the P2Y2 type. Confocal microscopy was used to show that ATP-induced $\mathrm{Ca}^{2+}$ release in cumulus cells leads to a $\mathrm{Ca}^{2+}$ increase in the oocyte. Inhibition of gap-junctional communication using carbenoxolone, as assayed by dye transfer, inhibited the diffusion of the $\mathrm{Ca}^{2+}$ signal from the cumulus cells to the oocyte. Thus, provided that a $\mathrm{Ca}^{2+}$ signal is generated in the somatic cells in response to maturation-inducing hormones, it is feasible that a $\mathrm{Ca}^{2+}$ transient is generated in the oocyte. However, FSH and EGF, both of which stimulate maturation in vitro, have no effect on $\mathrm{Ca}^{2+}$ in cumulus-oocyte complexes. Furthermore, LH, which leads to meiotic maturation in vivo, did not stimulate $\mathrm{Ca}^{2+}$ release in acutely isolated granulosa cells from preovulatory mouse follicles. These studies indicate that ATP may play a role in modulating ovarian function and that diffusion of $\mathrm{Ca}^{2+}$ signals through gap junctions may provide a means of communication between the somatic and germ cells of the ovarian follicle. However, our data are not consistent with a role for $\mathrm{Ca}^{2+}$-mediated communication in hormone-mediated induction of meiosis in mice.

\section{Introduction}

Mammalian oocytes are arrested in the first meiotic division until they are stimulated to undergo meiotic maturation just before ovulation. Meiotic maturation involves the progression from prophase of the first meiotic division to metaphase of the second meiotic division. In all mammalian species, the signal responsible for stimulating the resumption of meiosis is a surge of $\mathrm{LH}$. $\mathrm{LH}$ receptors are present on theca and granulosa cells and, in some species, the cumulus cells but not the oocyte. How this signal in the somatic compartment of the follicle is transduced to the oocyte to stimulate meiotic maturation is not understood.

Meiotic maturation can also be stimulated by release of the oocytes from the follicle into culture medium. This 'spontaneous' maturation indicates that the follicular environment may be responsible for maintaining meiotic arrest (Pincus and Enzmann, 1935; Edwards, 1965). To override meiotic arrest, LH may lead to the suppression of the putative inhibitory follicular signals or, alternatively, may provide a positive stimulus to override the follicular

*Correspondence

Email: j.carroll@ucl.ac.uk inhibition. One favoured mechanism for removing inhibitory follicular signals is the breakdown of gap junctions in the follicle (Larsen et al., 1986; Downs, 1995), which would effectively restrict the flow of any inhibitory signals from the follicular cells to the oocyte. However, gap-junctional coupling persists between the cumulus cells and the oocyte until after germinal vesicle breakdown (GVBD) in sheep and mouse oocytes (Moor et al., 1981; Eppig, 1982). The evidence that meiotic arrest is released by a positive stimulus is that hormonal stimuli in the form of LH (Dekel and Beers, 1978), FSH (Downs et al., 1988) and epidermal growth factor (EGF) (Downs, 1989; Downs et al., 1988) can override meiotic arrest in vitro. The action is apparently mediated by the cumulus cells and transmitted through gap junctions, as both are required for the hormonal stimulus to work (Fagbohun and Downs, 1991; Downs, 2001). Thus, with appropriate hormonal stimulation, the somatic compartment of the follicle can be induced to drive the resumption of meiosis in vitro. However, the nature of the signal is not known.

Clues to the identity of the signalling molecules responsible for maturation may be provided by messengers in the signal transduction pathways of the $\mathrm{LH}$ receptor. The $\mathrm{LH}$ receptor is a classic G-protein-coupled seven 

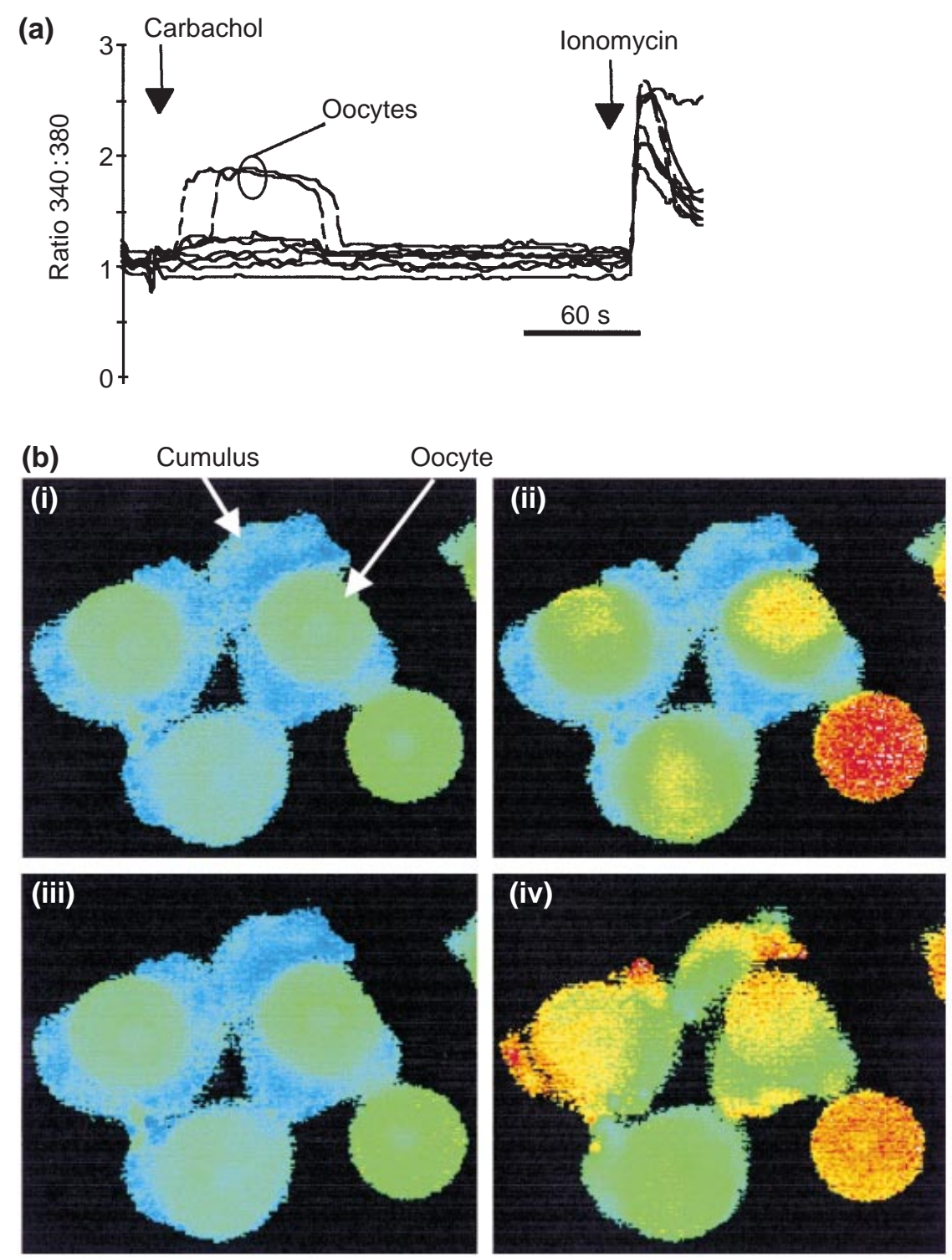

Fig. 1. Monitoring of $\mathrm{Ca}^{2+}$ concentration in mouse oocytes and cumulus cells. Fluorescence from fura 2-loaded, partially denuded oocytes was recorded. (a) Trace showing fluorescence ratio in cumulus cells (solid lines) and oocytes (dashed lines, circled) during application of carbachol $\left(100 \mu \mathrm{mol} \mathrm{I}^{-1}\right)$ to the bath to increase $\mathrm{Ca}^{2+}$ in the oocytes and application of ionomycin $\left(10 \mu \mathrm{mol} \mathrm{I}^{-1}\right)$ to increase $\mathrm{Ca}^{2+}$ in both the oocytes and cumulus cells. Each trace represents a single region of interest (ROI) in either the cumulus cells or oocyte. (b) A series of representative images showing pseudocoloured fluorescence ratio (i) before application of carbachol, (ii) at the peak of the carbachol increase, (iii) after recovery of the carbachol response and (iv) after application of ionomycin. A cumulus cell and oocyte are labelled in (i).

transmembrane receptor (Segaloff and Ascoli, 1993). It activates adenylate cyclase with the result that receptor stimulation leads to a rapid increase in the concentration of cAMP (Sanchez-Yague et al., 1993; Davis, 1994). Other reports indicate that LH may signal by stimulating the hydrolysis of phosphatidylinositol 4,5-bisphosphate $\left(\mathrm{PIP}_{2}\right)$, resulting in the production of 1,4,5-triphosphate $\left(\mathrm{InsP}_{3}\right)$ and the release of intracellular $\mathrm{Ca}^{2+}$ (Davis et al., 1986, 1991; Dimino et al., 1987; Goren et al., 1990; Gudermann et al., 1992; Flores et al., 1998). The ability of the messengers 
$\operatorname{Ins}_{3}, \mathrm{Ca}^{2+}$ and cAMP to participate in cell signalling via gap junctions (Saez et al., 1989; Sandberg et al., 1992) indicates that they may be good candidates for the messengers responsible for stimulation of oocyte maturation.

There are two main models for meiotic resumption involving these messengers. In the first model, maturation is stimulated by a transient increase in cAMP. Although cAMP is normally considered to be a negative regulator of meiotic maturation (Cho et al., 1974; Eppig, 1993; Downs, 1995), a number of lines of evidence indicate that it may also act as a positive regulator. Firstly, transient exposure of oocytes arrested with $200 \mu \mathrm{mol}$ dibutyryl cAMP $\mathrm{I}^{-1}$ to $1 \mathrm{mmol}$ dibutyryl CAMP $\left.\right|^{-1}$ stimulates the resumption of meiosis (Eppig, 1993; Downs, 1995). Secondly, a transient increase in CAMP in intact isolated follicles stimulates oocyte maturation (Dekel and Sherizly, 1983; Dekel et al., 1988; Yoshimura et al., 1992). Thirdly, a transient increase in cAMP has been reported in the oocyte several hours after the addition of LH to the follicle (Moor and Heslop, 1981). Thus, cAMP meets some of the requirements expected of a physiological regulator of meiotic maturation, but a causal link has yet to be established.

In the second model, $\mathrm{Ca}^{2+}$ transients generated in the follicular compartment diffuse to the oocyte, with a resultant increase in $\mathrm{Ca}^{2+}$ in the oocyte (Eppig, 1993; Homa et al., 1993). In support of this model are the findings that, in intact follicles, the ability of LH to stimulate meiotic resumption is inhibited by $\mathrm{Ca}^{2+}$-free medium (Goren et al., 1990) and that $\mathrm{Ca}^{2+}$ oscillations and phosphoinositide turnover occur during resumption of meiosis (Carroll and Swann, 1992; Carroll et al., 1994; Pesty et al., 1994; Homa, 1995). More recently, inhibitors of phosphoinositide metabolism and intracellular $\mathrm{Ca}^{2+}$ buffers have been shown to inhibit hormone-induced maturation in vitro (Coticchio and Fleming, 1998). Perhaps the most direct evidence for a role for $\mathrm{Ca}^{2+}$ is the finding that in sheep cumulus-oocyte complexes (COCs), $\mathrm{LH}$ stimulates a $\mathrm{Ca}^{2+}$ increase in the cumulus cells that is transmitted to the oocyte (Mattioli et al., 1998). Whether these $\mathrm{Ca}^{2+}$ changes occur in the granulosa cells of other species and what role they play in meiotic resumption is not known.

In this study, $\mathrm{Ca}^{2+}$ imaging techniques were used to test a number of hypotheses to determine whether increases in intracellular $\mathrm{Ca}^{2+}$ are important in $\mathrm{LH}$-induced resumption of meiosis in mice.

\section{Materials and Methods}

\section{Oocyte collection and culture}

Female MF1 mice were injected with 5-10 iu equine chorionic gonadotrophin (eCG) at $48 \mathrm{~h}$ before oocyte collection. For collection of the COCs, mice were killed by cervical dislocation and the ovaries were removed to warm M2 (Fulton and Whittingham, 1978). The large antral follicles on the surface of the ovary were punctured with a 27 -gauge needle and oocytes with an intact layer of
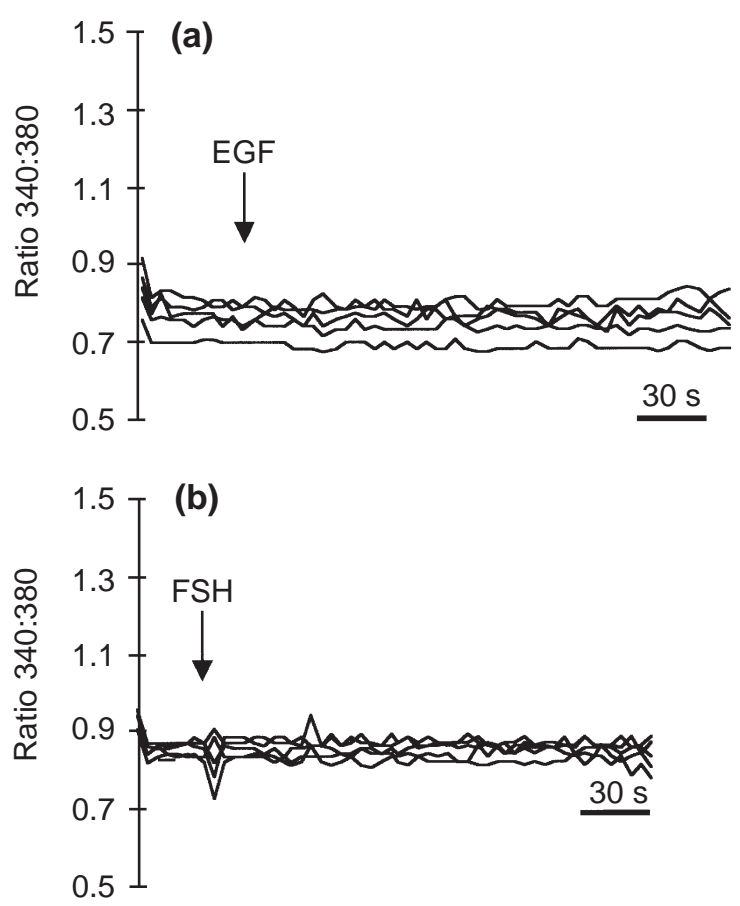

Fig. 2. Effects of epidermal growth factor (EGF) and FSH on resting $\mathrm{Ca}^{2+}$ concentration in mouse cumulus cells. Each trace represents a single region of interest (ROI) in the cumulus cells. Adminis-

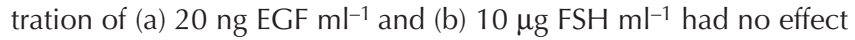
on $\mathrm{Ca}^{2+}$ concentrations.

cumulus cells were collected. The COCs were washed three times and maintained in $\mathrm{M} 2$ at $37^{\circ} \mathrm{C}$.

\section{Monitoring of $\mathrm{Ca}^{2+}$ in cumulus-oocyte complexes}

For the initial imaging experiments, COCs were pipetted through a pipette smaller than the diameter of the complex but larger than the diameter of the oocyte. This technique breaks the complex open, removing some of the cumulus cells in the process. These partially denuded complexes were incubated in $2 \mu \mathrm{mol}$ fura $2 \mathrm{I}^{-1}$ in $\mathrm{M} 2$ containing $0.02 \%$ $(\mathrm{w} / \mathrm{v})$ pluronic acid for $20 \mathrm{~min}$ at $37^{\circ} \mathrm{C}$. This allowed suitable loading of fura 2 into cumulus cells and the oocyte, and provided the basis of an assay to determine whether agonists could stimulate $\mathrm{Ca}^{2+}$ release in either the cumulus cells or the oocyte. $\mathrm{Ca}^{2+}$ was monitored by placing partially denuded complexes in a chamber containing $500 \mu \mathrm{l} \mathrm{M2}$ without BSA. After a few minutes to allow the complexes to stick to the glass coverslip base, an additional $500 \mu \mathrm{l}$ complete M2 was added to the chamber. The heated chamber containing the COCs was placed on the stage of a Zeiss Axiovert and imaged at $\times 20$ magnification with a $0.75 \mathrm{NA}$ objective. Fluorescence was collected using a Coolview camera and processed using lonVision software (ImproVision, Coventry). Data are presented as ratio of emission intensities acquired at excitation wavelengths of 340 and $380 \mathrm{~nm}$. The agonists were made up in M2 at 
(a)
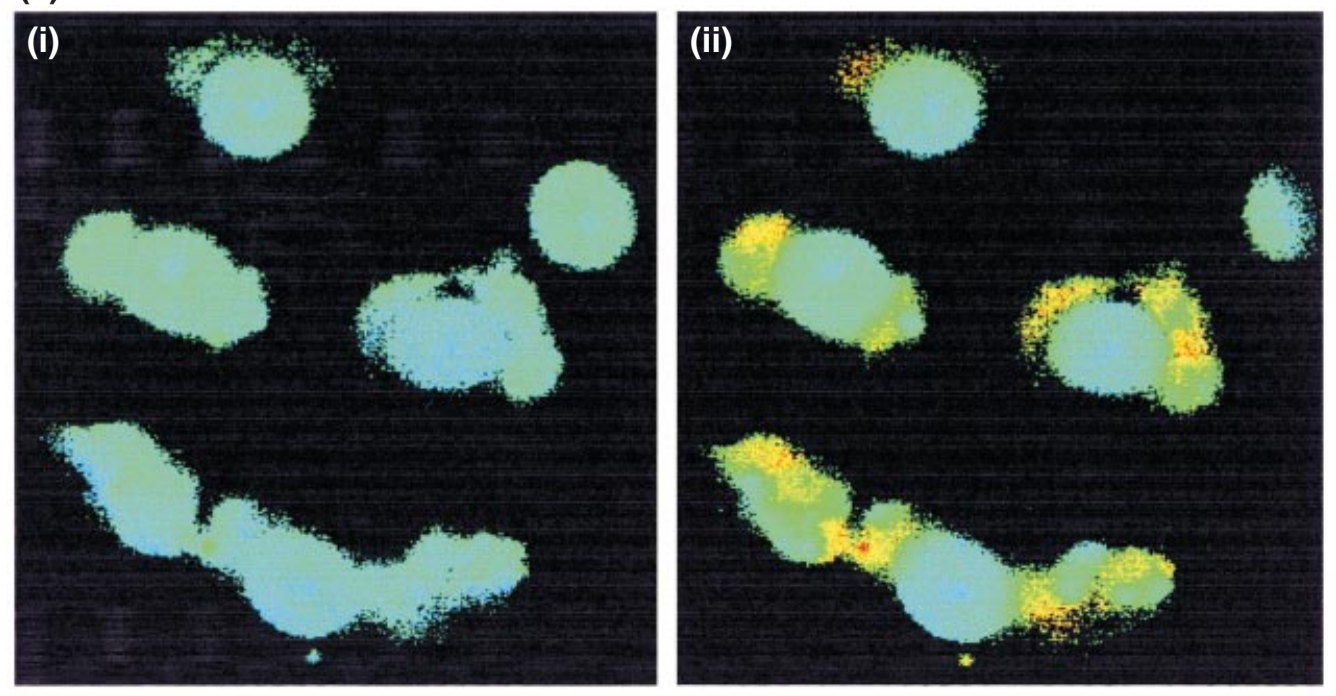

(b)

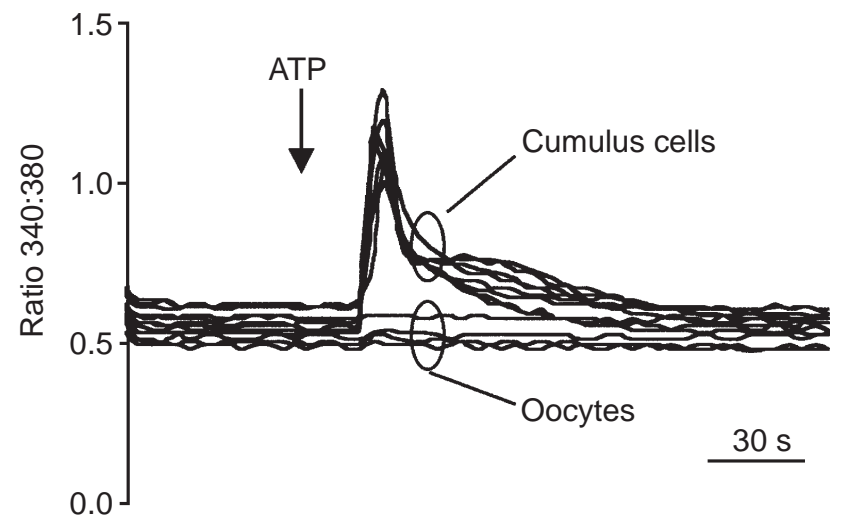

(c)

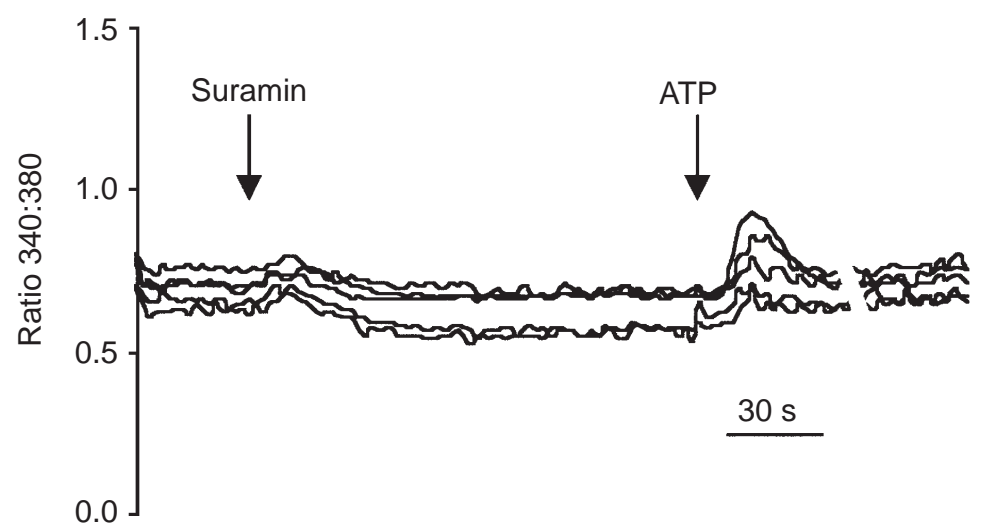

Fig. 3. ATP stimulated an increase in $\mathrm{Ca}^{2+}$ in mouse cumulus cells and this increase was inhibited by

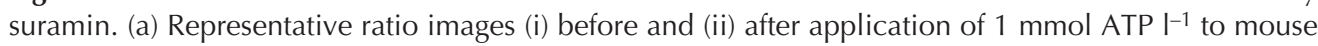
cumulus-oocyte complexes. Note the increase in fluorescence in the cumulus cells but not in the oocytes. (b) Each trace is the fluorescence ratio from either the oocyte or the cumulus cells, as labelled. (c) Suramin $\left(100 \mu \mathrm{mol} \mathrm{I}^{-1}\right)$ preincubation inhibited ATP-induced $\mathrm{Ca}^{2+}$ release in cumulus cells. 
$\times 10-100$ stock solutions and the appropriate volume was pipetted into the chamber during the recording to monitor the effects of agonists on $\mathrm{Ca}^{2+}$ in cumulus cells and oocytes. Images were acquired at 2-10 s intervals depending on the duration of the experiment.

Confocal imaging of changes in $\mathrm{Ca}^{2+}$ was performed using a BioRad $\mu$ Radiance confocal scanning head attached to a Zeiss Axiovert microscope. For injection of $\mathrm{Ca}^{2+}$ dyes into the oocyte, a holding pipette attached to a micrometer syringe was used to orient the COC while the injection pipette was inserted through the cumulus cell layers to the oocyte plasma membrane. Penetration of the plasma membrane was achieved by brief over-compensation of the negative capacitance. Fluo3 (5 mmol $\mathrm{I}^{-1}$ in the pipette) in injection buffer (120 mmol KCl $\mathrm{I}^{-1}$ and 20 mmol Hepes $\left.\mathrm{I}^{-1}\right)$ was pressure-injected using a Picopump (WPI) to a final concentration of 50-100 $\mu \mathrm{mol} \mathrm{I}^{-1}$. The cumulus cells were loaded by incubating intact COCs for $30 \mathrm{~min}$ at $37^{\circ} \mathrm{C}$ in $20 \mu \mathrm{mol}$ fluo $3 \mathrm{AM} \mathrm{I}^{-1}$ in $\mathrm{M}^{2}$ containing $200 \mu \mathrm{mol}$ dibutyryl cAMP I-1 and $0.02 \%(\mathrm{w} / \mathrm{v})$ pluronic acid.

For microinjection of fluoroscein to assess gap junction permeability, pipettes were backfilled with a solution of $1 \mathrm{mg}$ fluoroscein $\mathrm{ml}^{-1}$ in injection buffer before microinjection as described above. The complexes were placed in heated chambers as described above and the fluo3 was excited using the $488 \mathrm{~nm}$ line from an argon laser. Images were acquired every $2 \mathrm{~s}$ for $\mathrm{Ca}^{2+}$ experiments or every minute for fluoroscein experiments. Data were analysed off-line using Metamorph software.

\section{Results}

\section{Monitoring of $\mathrm{Ca}^{2+}$ in cumulus cells and oocytes}

Agonists known to increase intracellular $\mathrm{Ca}^{2+}$ were applied to establish that changes in cumulus cells and oocytes could be monitored using partially denuded COCs. Carbachol $\left(100 \mu \mathrm{mol}{ }^{-1}\right)$ increases $\mathrm{Ca}^{2+}$ concentration in oocytes via activation of muscarinic acetylcholine receptors (Carroll and Swann, 1992). An immediate increase in $\mathrm{Ca}^{2+}$ concentration in the oocyte was observed after addition of carbachol to fura 2-loaded COCs (Fig. 1). $\mathrm{No} \mathrm{Ca}^{2+}$ increase was observed in the cumulus cells; however, a large $\mathrm{Ca}^{2+}$ increase was reported after application of $10 \mu \mathrm{mol}$ ionomycin $\mathrm{I}^{-1}(n=8)$. These findings demonstrate that the experimental conditions allowed measurement of $\mathrm{Ca}^{2+}$ concentrations in oocytes and their attached cumulus cells.

\section{Agonist-induced $\mathrm{Ca}^{2+}$ release in cumulus cells}

Several candidate agonists were screened to examine the hypothesis that a $\mathrm{Ca}^{2+}$ increase in the somatic compartment of the follicle is passed to the oocyte via gap junctions. EGF and FSH stimulate mucification of the cumulus cells (Downs et al., 1988; Downs, 1989) and increase $\mathrm{Ca}^{2+}$ in a variety of cell types (Flores et al., 1990, 1992). Addition of $\operatorname{EGF}\left(20 \mathrm{ng} \mathrm{ml}^{-1} ; n=9\right)$ or FSH $\left(10 \mu \mathrm{g} \mathrm{ml}^{-1} ; n=10\right)$ to COCs failed to cause an increase in $\mathrm{Ca}^{2+}$ in either the cumulus
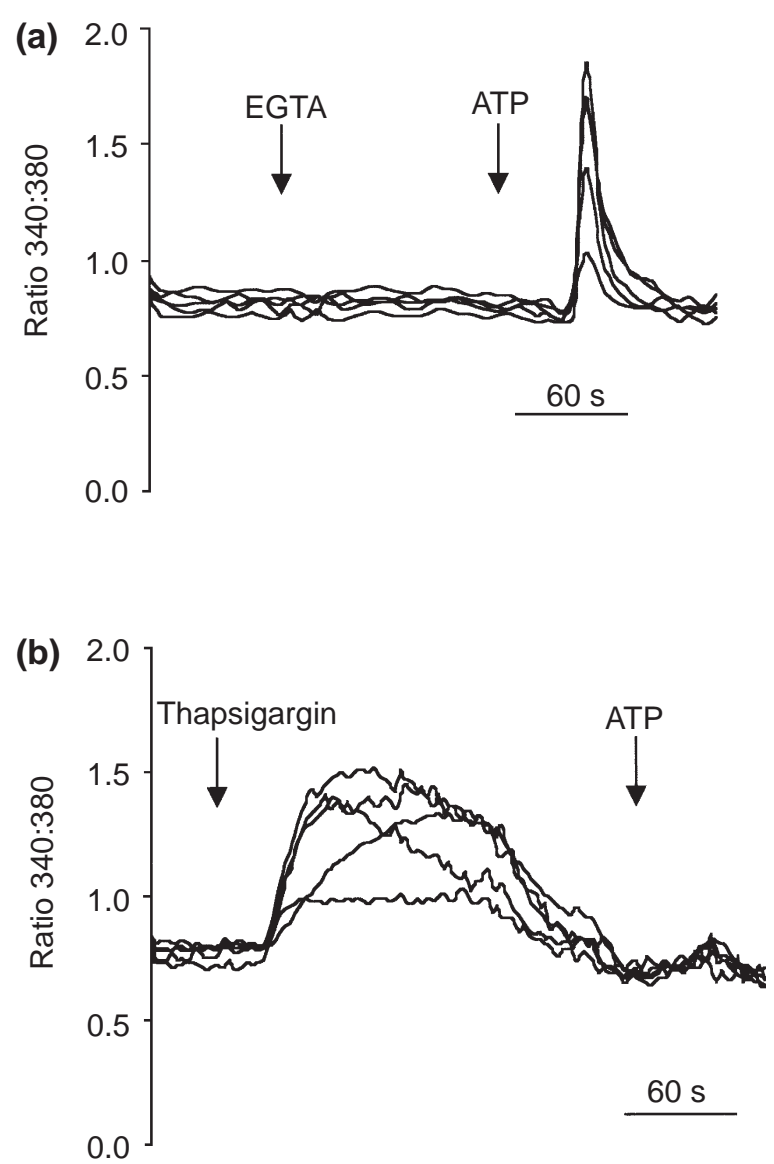

Fig. 4. ATP-induced release of $\mathrm{Ca}^{2+}$ from intracellular $\mathrm{Ca}^{2+}$ stores. (a) Addition of EGTA ( $2 \mathrm{mmol} \mathrm{I}^{-1}$ final concentration) to the bath before application of ATP $\left(500 \mu \mathrm{mol} \mathrm{I}^{-1}\right)$ had no effect on the ability of ATP to trigger $\mathrm{Ca}^{2+}$ release in mouse cumulus cells. (b) Depletion

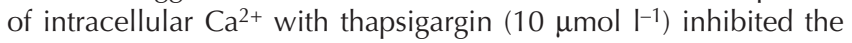
ability of ATP to stimulate $\mathrm{Ca}^{2+}$ release in mouse cumulus cells.

cells or oocyte (Fig. 2), despite induction of cumulus expansion in parallel experiments (data not shown). Angiotensin II $(n=5)$ and $\mathrm{GnRH}(n=5)$ increased $\mathrm{Ca}^{2+}$ in cultured granulosa cells (Currie et al., 1992); however, in the present study, no effect of either agent on $\mathrm{Ca}^{2+}$ concentrations in cumulus cells was observed. In addition, no increase in $\mathrm{Ca}^{2+}$ in response to dibutyryl cAMP $(1 \mathrm{mmol}$ $\left.\mathrm{I}^{-1} ; n=6\right)$ or forskolin $\left(200 \mu \mathrm{mol} \mathrm{I}^{-1} ; n=6\right)$ was observed (data not shown), although both have been reported to modify $\mathrm{Ca}^{2+}$ in ovarian cells of some species (Flores et al., 1992). LH was not tested because mouse cumulus cells do not express LH receptors (Eppig et al., 1997).

Effect of ATP on $\mathrm{Ca}^{2+}$ release in mouse cumulus cells via activation of $P 2$ receptors

The final agonist of $\mathrm{Ca}^{2+}$ release tested in the present study was ATP, as it stimulates $\mathrm{Ca}^{2+}$ release in ovarian cells from many species (chicken: Morley et al., 1994; human: 

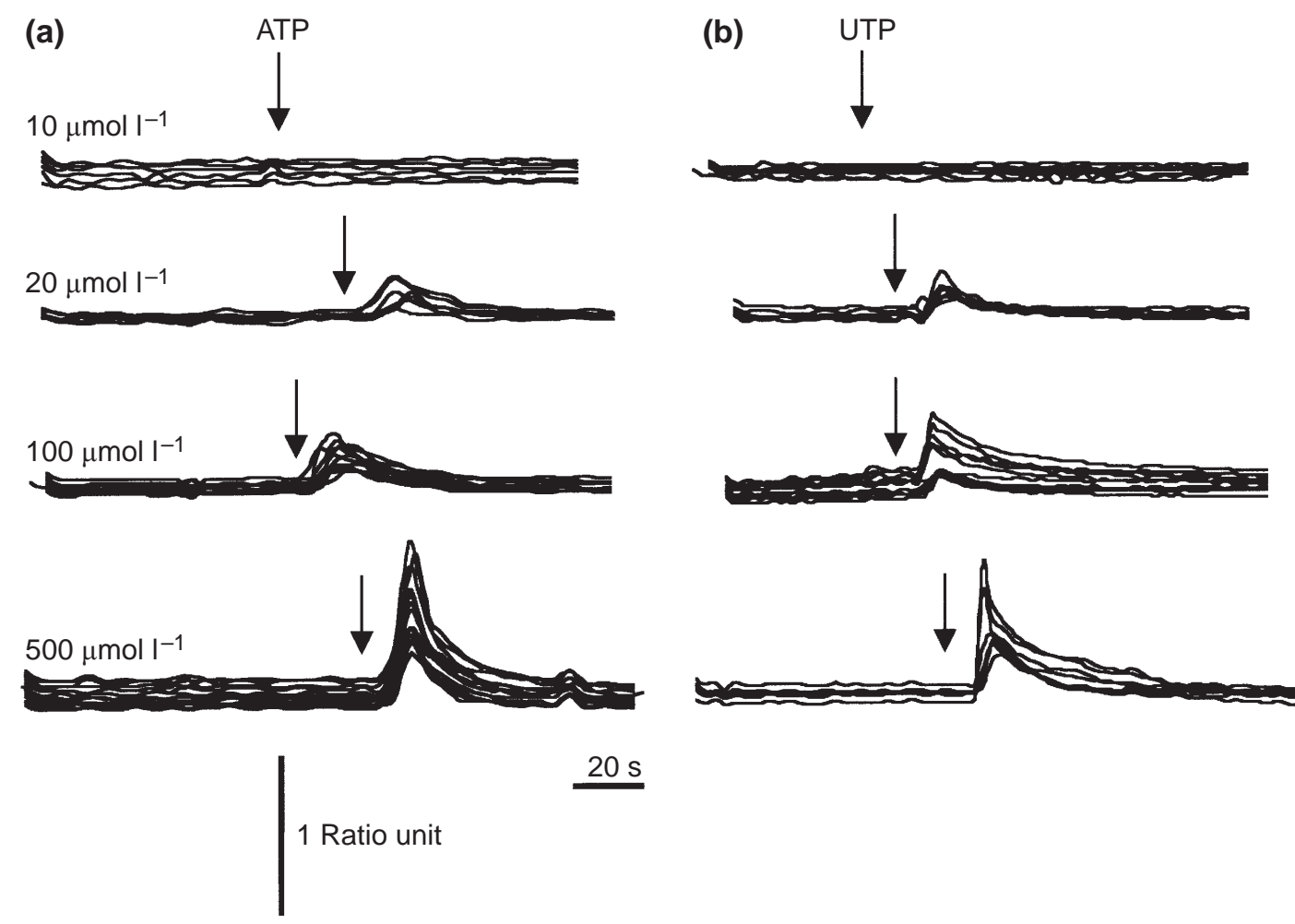

Fig. 5. ATP and UTP stimulated $\mathrm{Ca}^{2+}$ release in mouse cumulus cells with similar potencies. A dose-response curve for $\mathrm{Ca}^{2+}$ release in response to 10, 20, 100 and $500 \mu \mathrm{mol} \mathrm{I-1}$ (a) ATP and (b) UTP is shown. Time of addition of ATP or UTP is indicated by the arrow.

Lee et al., 1996; Squires et al., 1997; pig: Aguirre et al., 2000). ATP (between $250 \mu \mathrm{mol} \mathrm{I}^{-1}$ and $1 \mathrm{mmol} \mathrm{I}^{-1}$ ) stimulated a significant increase in intracellular $\mathrm{Ca}^{2+}$ concentration in cumulus cells $(n=33)$ (Fig. 3a,b). There was no evidence of any increase in $\mathrm{Ca}^{2+}$ in the oocyte (Fig. $3 a, b)$, indicating that gap-junctional coupling may be incapable of propagating the $\mathrm{Ca}^{2+}$ increase to the oocyte or that the gap junctions were not patent in the conditions of the experiment (see below).

Suramin is an effective inhibitor of $\mathrm{P} 2$ receptors and acts by blocking the ATP binding site. Application of $100 \mu \mathrm{mol}$ suramin $\mathrm{I}^{-1}$ before ATP inhibited the ability of ATP to increase $\mathrm{Ca}^{2+}$ concentration $(n=9)$ (Fig. 3c). P1 receptors linked to phosphoinositide turnover do not appear to be present on cumulus cells, as adenosine and 2-chloroadenosine did not increase intracellular $\mathrm{Ca}^{2+}$ concentration (data not shown).

\section{Partial characterization of the $P 2$ receptor subtype}

P2 receptors occur in two major forms: ligand-gated ion channels (P2X receptors) and G-protein-coupled receptors (P2Y) (Burnstock and King, 1996). The roles of extracellular and intracellular $\mathrm{Ca}^{2+}$ in the response to ATP were examined to determine whether the cumulus cells expressed the $\mathrm{P} 2 \mathrm{X}$ or $\mathrm{P} 2 \mathrm{Y}$ receptors. Removal of

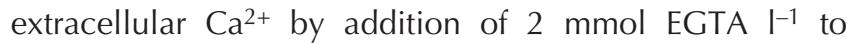
the chamber before addition of ATP had little effect on ATP-induced $\mathrm{Ca}^{2+}$ release $(n=21)$ (Fig. $\left.4 \mathrm{a}\right)$. This finding indicates that intracellular stores are probably the source of $\mathrm{Ca}^{2+}$ in response to ATP. The $\mathrm{Ca}^{2+}$-ATPase inhibitor, thapsigargin, was applied before ATP to deplete intracellular $\mathrm{Ca}^{2+}$. Application of ATP after depletion of intracellular $\mathrm{Ca}^{2+}$ stores failed to elicit an increase in $\mathrm{Ca}^{2+}$ $(n=15)$, further implicating $\mathrm{P} 2 \mathrm{Y}$ receptors in the ATP response (Fig. 4b).

\section{Effects of other di- and tri-nucleotides on $\mathrm{Ca}^{2+}$ in cumulus cells}

The effects of other tri- and di-nucleotides were examined to characterize further the $\mathrm{P} 2 \mathrm{Y}$ receptor present on cumulus cells. UTP stimulated $\mathrm{Ca}^{2+}$ release in cumulus cells with approximately equal potency to ATP. Doseresponse curves for ATP and UTP are shown (Fig. 5). No response was observed at $10 \mu \mathrm{mol} \mathrm{I}^{-1}$, whereas a small increase was observed at $20 \mu \mathrm{mol} \mathrm{I}{ }^{-1}$, which increased from $100 \mu \mathrm{mol} \mathrm{I} \mathrm{I}^{-1}$ to $500 \mu \mathrm{mol} \mathrm{I-1}$. This finding indicates that the receptor stimulated by these agents is equally sensitive to both agonists and, therefore, would be placed tentatively in the P2Y2 category (Burnstock and King, 1996).

No change in $\mathrm{Ca}^{2+}$ concentration was detected in 
response to $1-100 \mu \mathrm{mol}$ ADP $\mathrm{I}^{-1}$ (data not shown); however, higher concentrations (between $500 \mu \mathrm{mol} \mathrm{I}^{-1}$ and $1 \mathrm{mmol} \mathrm{I}^{-1}$ ) caused a small $\mathrm{Ca}^{2+}$ increase in the cumulus cells that appeared to be followed by an increase in $\mathrm{Ca}^{2+}$ concentration in the oocytes $(n=9)$ (Fig. 6a). In one experiment $(n=3)$, a further addition of $500 \mu \mathrm{mol}$ ADP $\mathrm{I}^{-1}$ caused an additional $\mathrm{Ca}^{2+}$ increase in the oocytes but not in the cumulus cells (Fig. 6a). This finding indicates that the ADP-induced $\mathrm{Ca}^{2+}$ increase in the oocytes is independent of the $\mathrm{Ca}^{2+}$ change in the cumulus cells, consistent with previous data for ATP and UTP. Further support for this is provided by the observation that ADP also increases $\mathrm{Ca}^{2+}$ concentration in oocytes denuded completely of cumulus cells $(n=3)$ (Fig. 6b). These experiments indicate that both cumulus cells and oocytes may have an ADP-sensitive receptor. One feature of the ADP response is that in all the COCs tested $(n=5)$, the oocyte remained capable of responding to an additional application of ADP, whereas cumulus cells did not (Fig. 6a,b).

\section{Effect of ATP on $\mathrm{Ca}^{2+}$ in the oocyte of intact cumulus-oocyte complexes}

As described above, ATP-induced $\mathrm{Ca}^{2+}$ release in partially denuded COCs did not lead to any increases in intracellular $\mathrm{Ca}^{2+}$ concentration in the attached oocytes. This finding indicates that $\mathrm{Ca}^{2+}$ and $\mathrm{InsP}_{3}$ are unable to traverse the processes and gap junctions between the cumulus cells and oocyte. To determine whether this is also true in intact COCs, fluo3 was microinjected into the oocyte and the cumulus cells were loaded with fluo3 AM; $\mathrm{Ca}^{2+}$ changes in the oocyte and cumulus cells were monitored using confocal microscopy. In intact COCs, ATP caused an increase in $\mathrm{Ca}^{2+}$ in the cumulus cells, which was followed $46.8 \pm 8.1 \mathrm{~s}(n=17)$ later by an increase in $\mathrm{Ca}^{2+}$ in the oocyte (Fig. 7a,b). This finding indicates that increases in $\mathrm{Ca}^{2+}$ in the cumulus cells lead to increases in $\mathrm{Ca}^{2+}$ in the oocyte provided that the cumulus cell layer is intact.

The increase in $\mathrm{Ca}^{2+}$ concentration in the oocyte may be brought about by two mechanisms. Firstly, the $\mathrm{Ca}^{2+}$ or $\operatorname{InsP}_{3}$ generated in the cumulus cells may diffuse through gap junctions and, secondly, ATP may induce the release of a messenger from cumulus cells that simulates a $\mathrm{Ca}^{2+}$ mobilizing receptor on the oocyte plasma membrane. The gap junction inhibitor, carbenoxolone, was applied

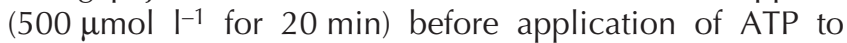
examine the role of gap junctions. Preincubation with carbenoxolone completely abolished the transfer of FITC-dextran from the oocyte to the cumulus cells, indicating that gap-junctional coupling was probably inhibited ( $n=5$ ) (Fig. 8a,b). In carbenoxolone-treated COCs, ATP-induced $\mathrm{Ca}^{2+}$ transients did not propagate from the cumulus cells to the oocyte $(n=6)$ (Fig. 9a,b). In two experiments, the ability of the oocyte to generate a $\mathrm{Ca}^{2+}$ increase was verified by application of carbachol (not shown). Thus, increases in $\mathrm{Ca}^{2+}$ in the cumulus cells can be transmitted to the oocyte via gap-junctional coupling.
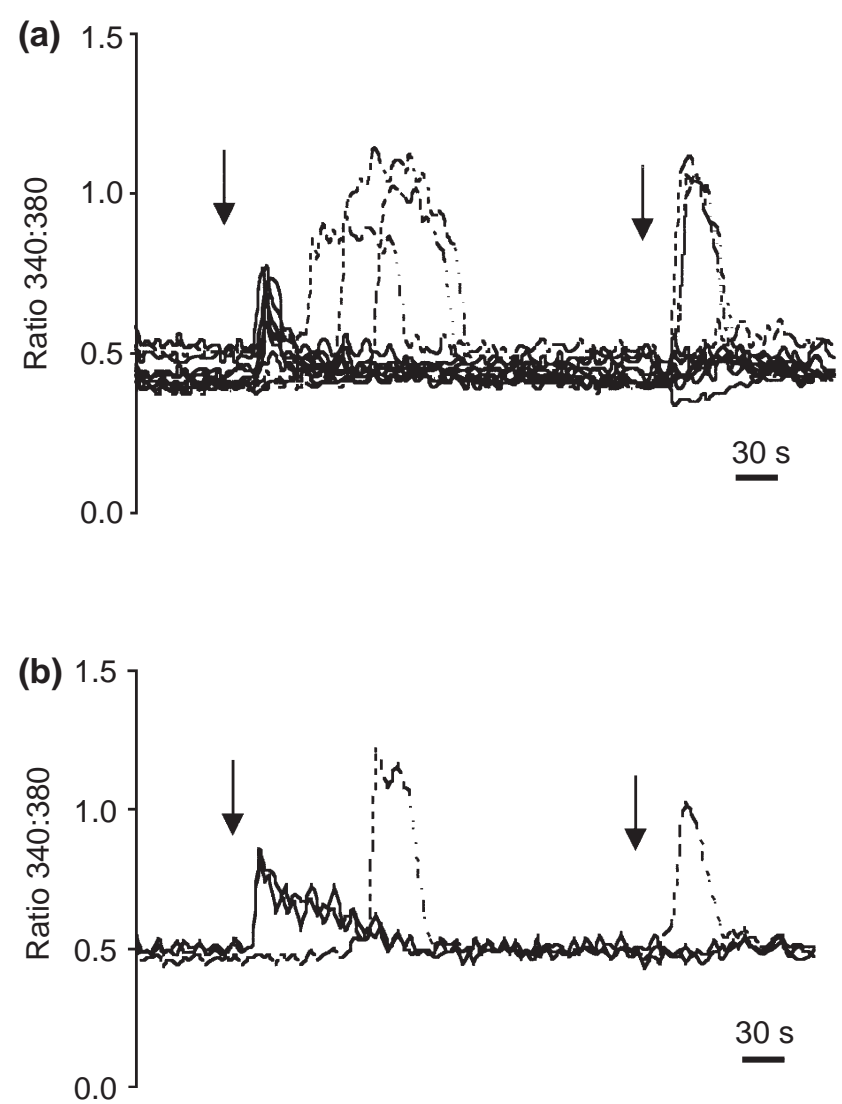

Fig. 6. Mouse oocytes and cumulus cells have an ADP receptor that stimulates $\mathrm{Ca}^{2+}$ release. (a) ADP was added to the bath as indicated by the arrows. A small increase in $\mathrm{Ca}^{2+}$ is visible in the cumulus cells (solid lines) and a larger change is apparent in the oocytes (dashed lines). Only the oocytes responded at the second addition of ADP. (b) Addition of ADP to a denuded oocyte. The denuded oocyte responded in a similar way to oocytes with some cumulus cells attached. Arrows indicate times of addition of $500 \mu \mathrm{mol} \mathrm{ADP} \mathrm{I}{ }^{-1}$.

\section{Effect of $\mathrm{LH}$ on $\mathrm{Ca}^{2+}$ in granulosa cells}

The ability of $\mathrm{LH}$ to increase $\mathrm{Ca}^{2+}$ in the somatic compartment of the follicle would provide support for a role for $\mathrm{Ca}^{2+}$ in meiotic resumption in vivo. However, to date, the physiological agonists FSH and EGF have not been found to influence $\mathrm{Ca}^{2+}$ in cumulus cells. Granulosa cells were recovered from individual follicles from PMSGprimed ovaries to determine whether $\mathrm{LH}$ may stimulate a $\mathrm{Ca}^{2+}$ increase in mouse follicular cells. The application of $\mathrm{LH}\left(1-10 \mu \mathrm{g} \mathrm{ml}^{-1}\right)$ did not cause an increase in $\mathrm{Ca}^{2+}$ in granulosa cells in three separate experiments. ATP was applied to confirm that the granulosa cells were responding to agonists. Similar to its effects on cumulus cells, ATP caused an increase in $\mathrm{Ca}^{2+}$ concentration in granulosa cells (Fig. 10). 


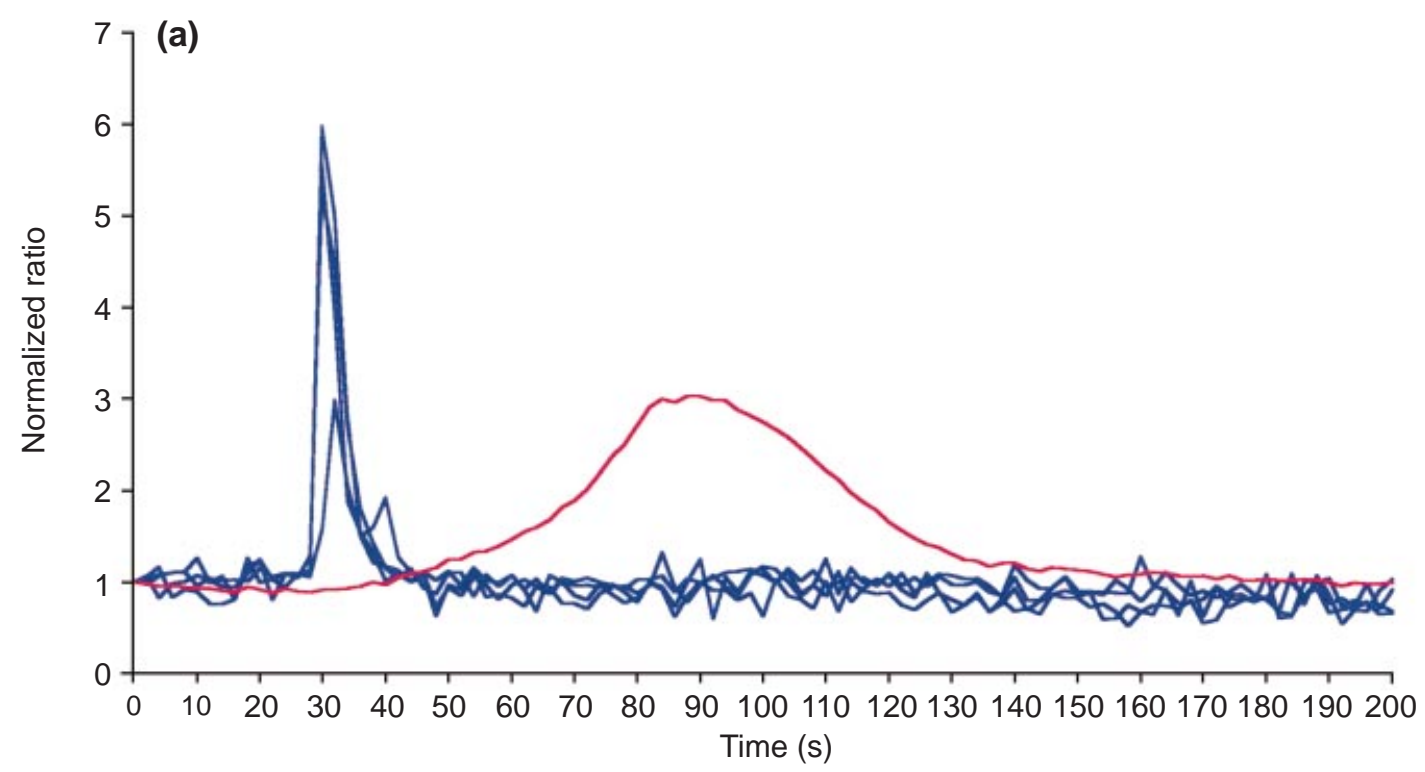

(b)

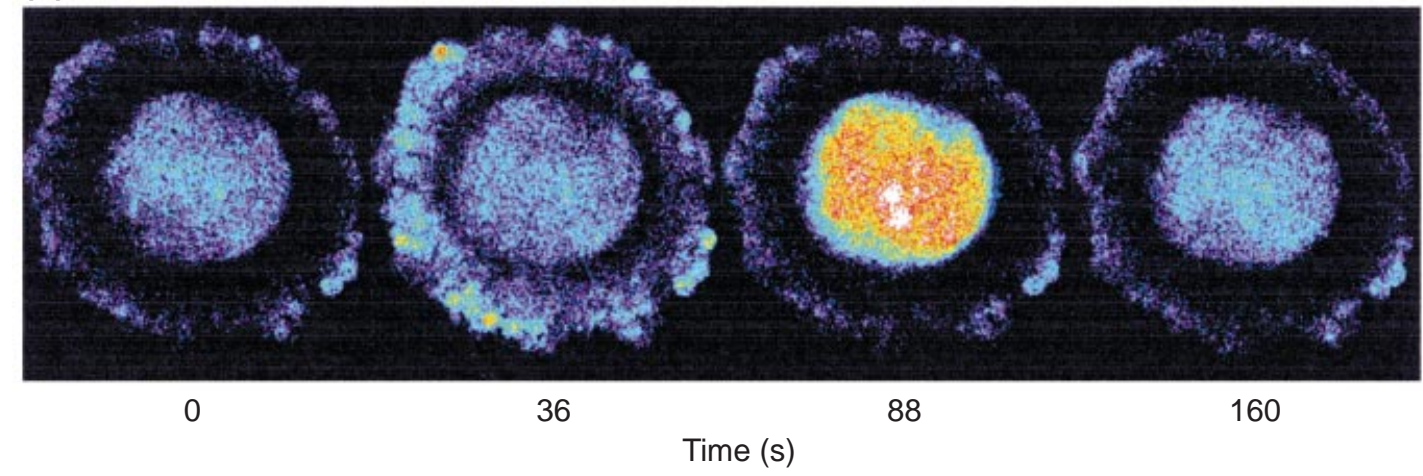

Fig. 7. ATP-induced $\mathrm{Ca}^{2+}$ waves travelled from mouse cumulus cells to the oocyte. (a) Fluorescence changes in different cumulus cells (blue traces) and the oocyte (red trace) in a representative mouse cumulus-oocyte complex. Note that the $\mathrm{Ca}^{2+}$ increase in the cumulus cells is followed by an increase in the oocyte. (b) A series of confocal images showing the cumulus cells and the oocyte. Images were acquired at the times indicated.

\section{Discussion}

The cell signalling pathway underlying hormone-induced meiotic maturation is essentially a problem of cell-cell signalling. How does the oocyte detect the binding of LH to receptors on the theca and granulosa cells? In the present study, conventional and confocal imaging techniques were used to monitor $\mathrm{Ca}^{2+}$ concentration in oocytes, cumulus cells and granulosa cells. It was found that ATP and UTP, but not FSH or EGF, cause $\mathrm{Ca}^{2+}$ transients in mouse follicular cells, that ATP-induced $\mathrm{Ca}^{2+}$ changes in cumulus cells can be passed to the oocyte via gap junctions and, finally, that $\mathrm{LH}$ has no effect on $\mathrm{Ca}^{2+}$ concentration in granulosa cells. These data provide evidence against a role for phosphoinositide turnover and $\mathrm{Ca}^{2+}$ transients in hormone-induced maturation in mice.
Experiments in the present study were designed to identify agonists of $\mathrm{Ca}^{2+}$ release in cumulus cells with the aim of determining whether changes in $\mathrm{Ca}^{2+}$ in cumulus cells could diffuse to the oocyte. Despite the fact that there are many agents that release $\mathrm{Ca}^{2+}$ in populations of ovarian cells from a number of species (Flores et al., 1990, 1992; Currie et al., 1992), the results of the present study indicate that mouse cumulus cells respond to few agonists of $\mathrm{Ca}^{2+}$ release. Of the agonists tested, only ATP and UTP consistently resulted in an increase in $\mathrm{Ca}^{2+}$ in cumulus cells. The P2 receptor subtype is apparently the G-proteincoupled P2Y family, as the ability of ATP to increase $\mathrm{Ca}^{2+}$ concentration was not dependent on extracellular $\mathrm{Ca}^{2+}$ and required intracellular $\mathrm{Ca}^{2+}$ stores. Furthermore, the similar sensitivity of the response to both ATP and UTP indicates that the receptor may be a P2Y2 receptor (Fredholm et al., 
1994; Burnstock and King, 1996). In addition to the putative $\mathrm{P} 2 \mathrm{Y} 2$ receptor, there is also evidence from the present study for an ADP receptor on both the cumulus cells and the oocyte. In most tissues, ecto-ATPases are responsible for metabolizing ATP, producing ADP in the process (Dubyak and El-Moatassim, 1993). This process provides a source of extracellular ATP, perhaps from hypoxic (Forrester, 1990) or dying cumulus cells, to initiate $\mathrm{Ca}^{2+}$ transients in the oocyte. ATP increases $\mathrm{Ca}^{2+}$ concentration in chicken, pig and human granulosa cells (chicken: Morley et al., 1994; human: Lee et al., 1996; Squires et al., 1997; pig: Aguirre et al., 2000), which indicates that P2 receptor-mediated regulation of follicular function is widely conserved. P2 signalling pathways regulate many physiological processes (Gordon, 1986; Dubyak and El-Moatassim, 1993), but their role in ovarian function is not known. One possibility is that ATP from sympathetic nerve terminals or dying cells (Stefenson et al., 1981; Gordon, 1986) leads to the release of $\mathrm{Ca}^{2+}$ in the somatic compartment of the follicle and that this $\mathrm{Ca}^{2+}$ modulates the sensitivity of follicular cells to steroid and peptide hormones (Sadighian et al., 1989; Bodis et al., 1993; Davis, 1994). Thus, ATP may act as a paracrine mediator of follicular development. Recent evidence showing that ATP activates MAP kinase in human granulosa-lutein cells supports this idea (Tai et al., 2001)

The finding of an agonist, ATP, that stimulates $\mathrm{Ca}^{2+}$ increases specifically in the cumulus cells provides the opportunity to determine whether a $\mathrm{Ca}^{2+}$ increase in the somatic compartment of the follicle is followed by a $\mathrm{Ca}^{2+}$ transient in the oocyte. Our data using confocal microscopy demonstrate clearly that ATP-induced $\mathrm{Ca}^{2+}$ increases in cumulus cells are followed by $\mathrm{Ca}^{2+}$ increases in the oocyte. Early experiments using conventional imaging of partially denuded COCs indicated that no cell-cell communication was taking place. The difference between intact and partially denuded COCs indicates that a full complement of gap junctions is required for sufficient diffusion of the messengers, or that the partial denuding process, perhaps by stimulating an increase in intracellular $\mathrm{Ca}^{2+}$ (Arellano et al., 1990), inhibits gap-junctional communication in the remaining cells. Whatever the mechanism, these findings demonstrate that, during in vitro maturation, an intact COC is required for normal gap-junctional communication between the oocyte and cumulus cells.

The increase in $\mathrm{Ca}^{2+}$ concentration in oocytes after stimulation of intact COCs with ATP appeared to be stimulated via diffusion through gap junctions. Gap junction inhibitors that prevent dye transfer between oocyte and cumulus cells also abolished the ability of ATP-induced $\mathrm{Ca}^{2+}$ transients in the cumulus cells to reach the oocyte. The messenger diffusing through gap junctions may be $\mathrm{InsP}_{3}$ or $\mathrm{Ca}^{2+}$. In the case of the COC, where the gap junction forms at the end of a narrow process that winds through the zona pellucida (Anderson and Albertini, 1976), the distance required for diffusion is at least $7 \mu \mathrm{m}$. As $\mathrm{Ca}^{2+}$ is heavily buffered by cytosol (Allbritton et al., 1992), it is likely that Ins $_{3}$ is the diffusible messenger. Irrespective of which

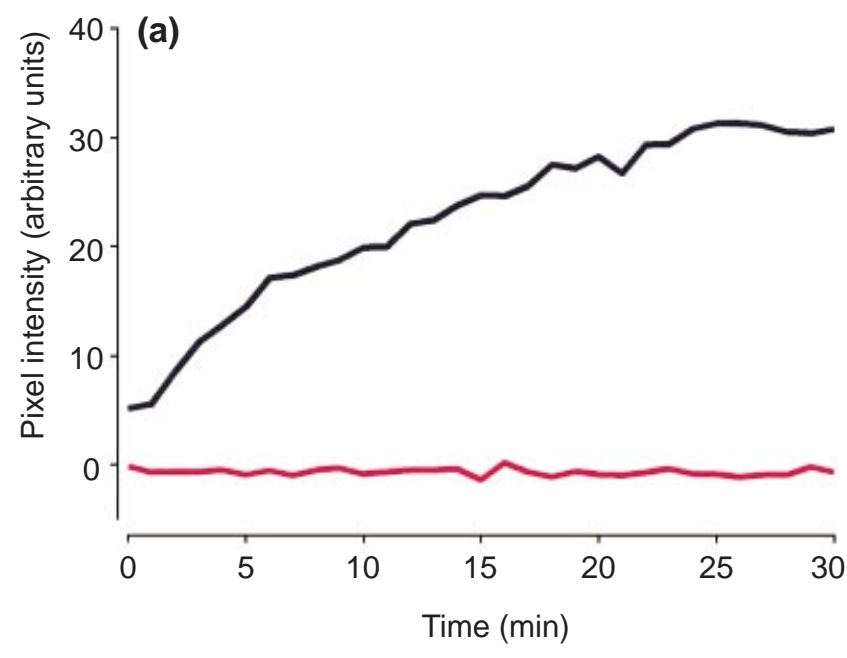

(b)

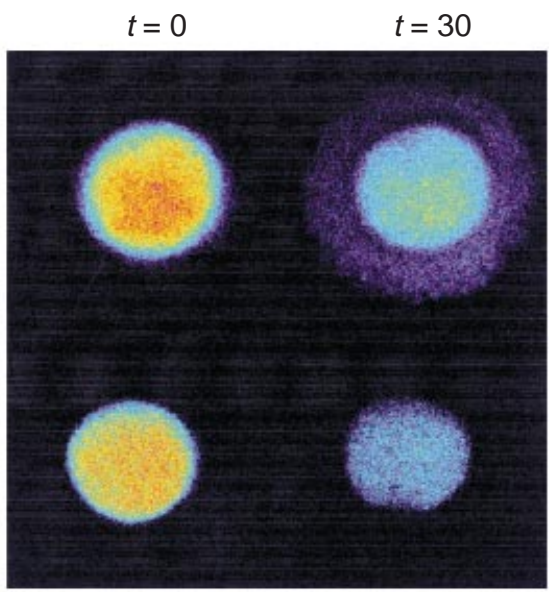

Fig. 8. Carbenoxolone inhibits dye transfer between mouse oocyte and cumulus cells. (a) Fluorescence in arbitrary units in the cumulus cells in control (black) and carbenoxolone-treated (red) mouse cumulus-oocyte complexes. (b) Representative images at the start and end of the 30 min recording. Oocytes were injected with fluoroscein and fluorescence was recorded in the cumulus cells and oocyte for $30 \mathrm{~min}$ in the presence or absence of carbenoxolone. Note that the fluorescence did not diffuse into associated cumulus cells. The decrease in fluorescence in the oocyte is a result of photobleaching of the fluoroscein.

messenger molecule is diffusing between cumulus cells and oocytes, these studies demonstrate that if the hormone responsible for meiotic maturation leads to an increase in $\mathrm{Ca}^{2+}$ in the somatic compartment of the follicle, it may be transmitted to the oocyte.

Hormone-induced in vitro maturation is stimulated by FSH and EGF (Downs et al., 1988; Eppig, 1991), and the signal responsible for stimulation of maturation apparently requires intact gap-junctional communication (Fagbohun and Downs, 1991). Thus, $\mathrm{Ca}^{2+}$ is a good candidate as the mediator of hormone-induced meiotic maturation. 


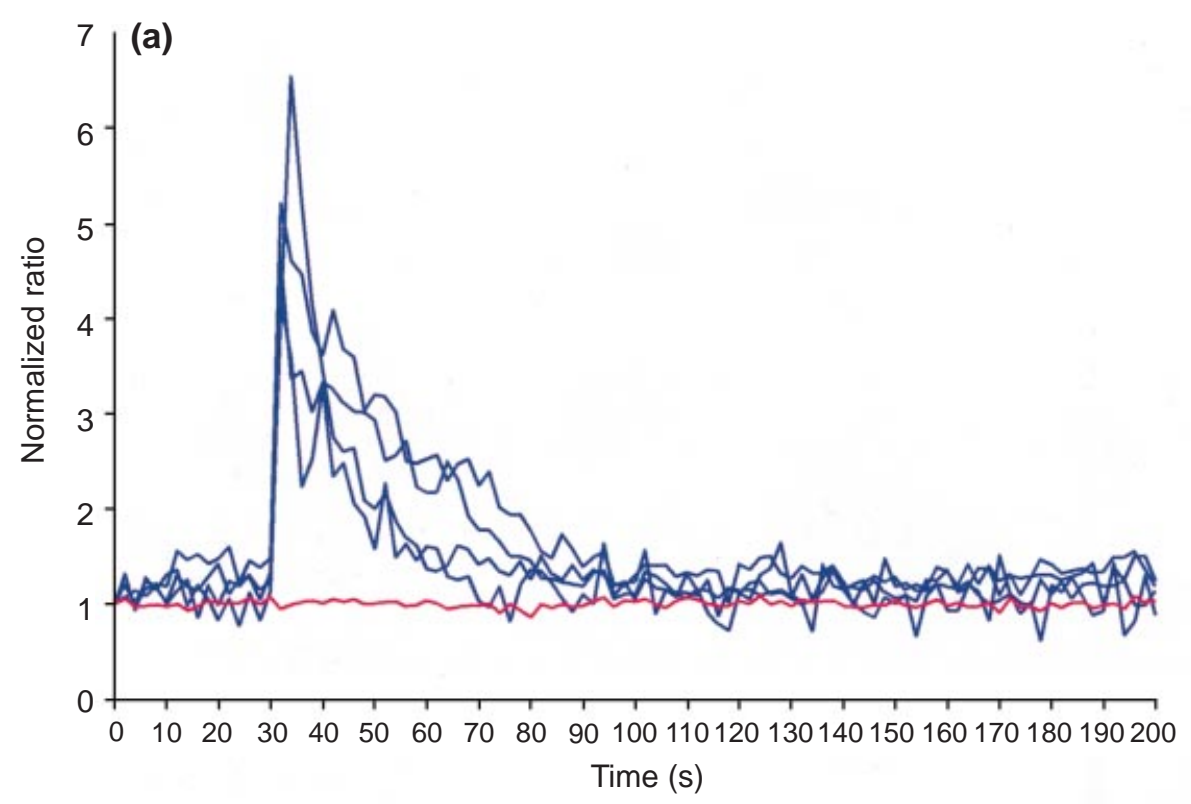

(b)

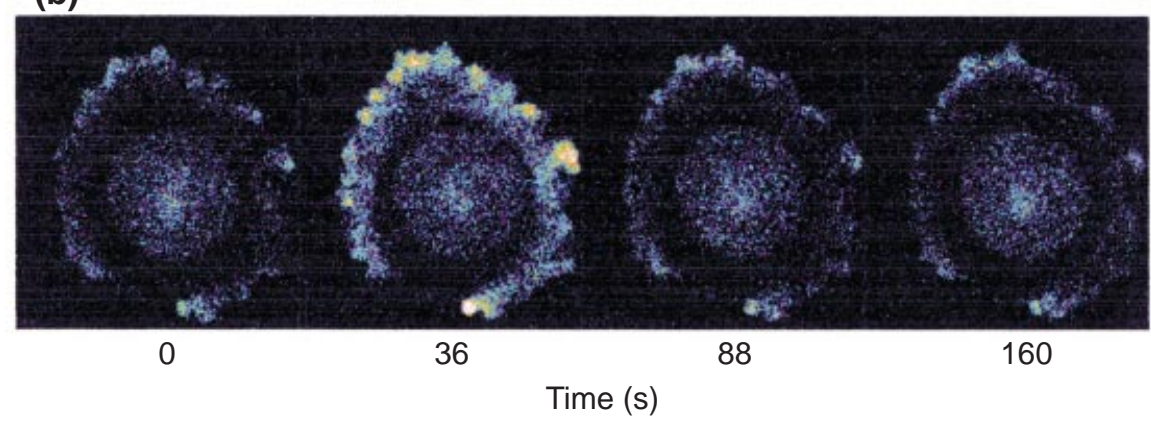

Fig. 9. Inhibition of gap-junctional communication inhibited ATP-induced $\mathrm{Ca}^{2+}$ transients in mouse oocytes. (a) Trace of fluo3 fluorescence from cumulus cells (blue) and oocyte (red) and (b) images of the same cell at selected times during recording. Data are from a representative mouse cumulus-oocyte complex preincubated for 20 min in carbenoxolone.

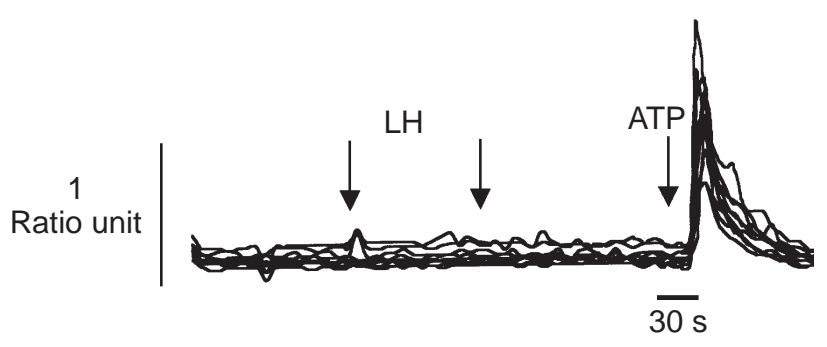

Fig. 10. LH did not stimulate $\mathrm{Ca}^{2+}$ release in freshly isolated mouse granulosa cells. Addition of $\mathrm{LH}\left(10 \mu \mathrm{g} \mathrm{ml}^{-1}\right)$ at the times indicated (arrows) did not modify intracellular $\mathrm{Ca}^{2+}$ concentration. Subsequent addition of $1 \mathrm{mmol} \mathrm{I}^{-1}$ ATP showed that granulosa cells also respond to ATP.

However, in this system there was no evidence to implicate $\mathrm{Ca}^{2+}$ in $\mathrm{FSH}-$ or EGF-induced maturation. The finding that neither agonist promoted an increase in $\mathrm{Ca}^{2+}$ indicates that their mode of action is via the stimulation of other signal transduction pathways, probably involving CAMP and tyrosine kinases, respectively. The lack of evidence for $\mathrm{Ca}^{2+}$ in hormone-induced maturation is in contrast to a recent study in which inhibition of phosphoinositide signalling and $\mathrm{Ca}^{2+}$ transients using lithium chloride, neomycin and BAPTA all inhibited hormone-induced but not spontaneous maturation (Cottichio and Fleming, 1988). As there was no evidence for an increase in $\mathrm{Ca}^{2+}$ in response to $\mathrm{FSH}$ and EGF in the present study, it remains to be shown that the inhibitors used to block phosphoinositide metabolism and $\mathrm{Ca}^{2+}$ transients were operating in the intended manner. In contrast to $\mathrm{Ca}^{2+}$, there is compelling evidence for a role for cAMP in mediating FSH-induced maturation. Firstly, it is well established that FSH stimulates CAMP production in granulosa cells (Richards, 1980) and, secondly, analogues of cAMP can mimic the ability of FSH to induce meiotic 
maturation in vitro (for reviews, see Eppig, 1993; Downs, 1995). Thus, the stimulus (FSH) increases cAMP and an increase in CAMP is sufficient to stimulate maturation. A lack of a specific method for inhibiting the generation of cAMP means that further studies must be undertaken to determine whether it is a necessity for hormone-induced maturation. On the basis of these data, an increase in cAMP, rather than $\mathrm{Ca}^{2+}$, remains the best candidate for mediating hormone-induced maturation in vitro in mice.

In vivo maturation is stimulated by the action of $\mathrm{LH}$ on the granulosa cells. It is not clear how LH leads to the stimulation of maturation. The studies described above do not discount a role for $\mathrm{Ca}^{2+}$ in the induction of maturation in intact follicles. If LH stimulates an increase in $\mathrm{Ca}^{2+}$ in the granulosa cells, it remains possible that this $\mathrm{Ca}^{2+}$ may reach the oocyte via gapjunctional communication (Eppig, 1993; Homa et al., 1993). This hypothesis was tested in the present study but it was found that $\mathrm{LH}$ had no effect on $\mathrm{Ca}^{2+}$ in granulosa cells from mouse follicles. Thus, there is little evidence to support a role for $\mathrm{Ca}^{2+}$ in stimulating maturation in intact follicles in mice. Species differences are apparent. $\mathrm{LH}$ has been shown to increase $\operatorname{Ins}_{3}$ production in granulosa cells (Davis et al., 1986; Dimino et al., 1987), although there is a delay of several minutes between $\mathrm{LH}$ application and detection of $\operatorname{Ins}_{3}$. The differentiation status of granulosa cells in culture may explain some of these differences. The most recent data indicating that $\mathrm{Ca}^{2+}$ transients may be involved in hormone-induced maturation is the finding that in sheep COCs, LH triggers a $\mathrm{Ca}^{2+}$ increase that is observed in the oocyte within $5 \mathrm{~min}$. Like ATP-induced $\mathrm{Ca}^{2+}$ changes in mice, the $\mathrm{Ca}^{2+}$ transient in the sheep oocyte is apparently dependent on intact gap junctions.

In conclusion, the results of the present study demonstrate that $\mathrm{Ca}^{2+}$ waves generated in the somatic compartment of mouse follicles can travel between heterologous gap junctions and stimulate $\mathrm{Ca}^{2+}$ transients in the oocyte. This finding demonstrates that $\mathrm{Ca}^{2+}$ may be an important mediator of cell-cell communication between the oocyte and the somatic cells of the ovary. However, the inability of FSH, EGF and $\mathrm{LH}$ to stimulate $\mathrm{Ca}^{2+}$ release in mouse follicular cells indicates that $\mathrm{Ca}^{2+}$ is probably not central to the mechanism of hormone-induced oocyte maturation in mice.

The authors would like to thank the extensive purinergic community at UCL for advice and reagents throughout this study, in particular B. King, G. Burnstock, F. Edwards and S. Robertson. The authors would also like to thank K. Swann for discussions and comments on the manuscript. This work was supported by grants from the MRC.

\section{References}

Aguirre C, Jayes FC and Veldhuis JD (2000) Luteinizing hormone (LH) drives diverse intracellular calcium second messenger signals in isolated porcine ovarian thecal cells: preferential recruitment of intracellular $\mathrm{Ca}^{2+}$ oscillatory cells by higher concentrations of LH Endocrinology 141 2220-2228

Allbritton NL, Meyer T and Stryer L (1992) Range of messenger action of calcium ion and inositol 1,4,5-trisphosphate Science 258 1812-1815

Anderson E and Albertini DF (1976) Gap junctions between the oocyte and companion follicle cells in the mammalian ovary Journal of Cell Biology $71680-686$

Arellano RO, Rivera A and Ramon F (1990) Protein phosphorylation and hydrogen ions modulate calcium-induced closure of gap junction channels Biophysical Journal 57 363-367

Bodis J, Tinneberg HR, Papenfuss F, Torok A, Cledon P, Hanf V and Schwarz H (1993) Cholinergic stimulation of progesterone and estradiol secretion by human granulosa cells cultured in serum-free medium Gynecology and Endocrinology 7 83-87

Burnstock G and King BF (1996) Numbering of cloned P2 purinoceptors Drug Development and Research 38 67-71

Carroll J and Swann K (1992) Spontaneous cytosolic calcium oscillations driven by inositol trisphosphate occur during in vitro maturation of mouse oocytes Journal of Biological Chemistry 267 11 196-11 201

Carroll J, Swann K, Whittingham D and Whitaker M (1994) Spatiotemporal dynamics of intracellular $\left[\mathrm{Ca}^{2+}\right]_{i}$ Development $1203507-3517$

Cho WK, Stern S and Biggers JD (1974) Inhibitory effect of dibutyryl cAMP on mouse oocyte maturation in vitro. Journal of Experimental Zoology $187383-386$

Coticchio G and Fleming S (1998) Inhibition of phosphoinositide metabolism or chelation of intracellular calcium blocks FSH-induced but not spontaneous meiotic resumption in mouse oocytes Developmental Biology 203 201-209

Currie WD, Li W, Baimbridge KG, Yuen BH and Leung PC (1992) Cytosolic free calcium increased by prostaglandin F2 alpha (PGF2 alpha), gonadotropin-releasing hormone, and angiotensin II in rat granulosa cells and PGF2 alpha in human granulosa cells Endocrinology 130 1837-1843

Davis JS (1994) Mechanisms of hormone action: luteinizing hormone receptors and second-messenger pathways Current Opinions in Obstetrics and Gynecology 6 254-261

Davis JS, Weakland LL, West LA and Farese RV (1986) Luteinizing hormone stimulates the formation of inositol trisphosphate and cyclic-AMP in rat granulosa-cells Biochemical Journal 238 597-604

Davis JS, Weakland LL, Farese RV and West LA (1991) Luteinizing hormone increases inositol trisphosphate and cytosolic free $\mathrm{Ca}^{2+}$ in isolated bovine luteal cells Journal of Biological Chemistry 262 8515-8521

Dekel N and Beers WH (1978) Rat oocyte maturation in vitro: relief of cyclic AMP inhibition by gonadotropins Proceedings National Academy of Sciences USA 75 4369-4373

Dekel $\mathbf{N}$ and Sherizly I (1983) Induction of maturation in rat follicleenclosed oocyte by forskolin FEBS Letters 151 153-155

Dekel N, Galiani D and Sherizly I (1988) Dissociation between the inhibitory and the stimulatory action of CAMP on maturation of rat oocytes Molecular and Cellular Endocrinology 56 115-121

Dimino MJ, Snitzer J and Brown KM (1987) Inositol phosphate accumulation in ovarian granulosa after stimulation by luteinizing hormone Biology of Reproduction 37 1129-1134

Downs SM (1989) Specificity of epidermal growth factor action on maturation of the murine oocyte and cumulus oophorus in vitro. Biology of Reproduction 41 371-379

Downs SM (1995) Control of the resumption of meiotic maturation in mammalian oocytes. In Gametes: The Oocyte pp 150-192 Eds JG Grudzinskas and JL Yovich. Cambridge University Press, Cambridge

Downs SM (2001) A gap-junction-mediated signal, rather than an external paracrine factor, predominates during meiotic induction in isolated mouse oocytes Zygote $\mathbf{9}$ 71-82

Downs SM, Daniel SA and Eppig JJ (1988) Induction of maturation in cumulus cell-enclosed mouse oocytes by follicle-stimulating hormone and epidermal growth factor: evidence for a positive stimulus of somatic cell origin Journal of Experimental Zoology 245 86-96

Dubyak GR and El-Moatassim C (1993) Signal transduction via P2purinergic receptors for extracellular ATP and other nucleotides American Journal of Physiology 265 C577-C606

Edwards RG (1965) Maturation in vitro of mouse, sheep, cow, pig, rhesus monkey and human ovarian oocytes Nature 208 349-351

Eppig J (1982) The relationship between cumulus cell-oocyte coupling, oocyte meiotic maturation, and cumulus expansion Developmental Biology 89 268-272 
Eppig J (1991) Intercommunication between mammalian oocytes and companion somatic cells BioEssays 13 569-574

Eppig JJ (1993) Regulation of mammalian oocyte maturation. In The Ovary pp 185-208 Eds EY Adashi and PCK Leung. Raven Press, New York

Eppig JJ, Wigglesworth K, Pendola F and Hirao Y (1997) Murine oocytes suppress expression of luteinizing hormone receptor messenger ribonucleic acid by granulosa cells Biology of Reproduction 56 976-984

Fagbohun CF and Downs SM (1991) Metabolic coupling and ligandstimulated meiotic maturation in the mouse oocyte-cumulus cell complex Biology of Reproduction 45 851-859

Flores JA, Veldhuis JD and Leong DA (1990) Follicle-stimulating hormone evokes an increase in intracellular free calcium ion concentrations in single ovarian (granulosa) cells Endocrinology 127 3172-3179

Flores JA, Leong DA and Veldhuis JD (1992) Is the calcium signal induced by follicle-stimulating hormone in swine granulosa cells mediated by adenosine cyclic 3',5'-monophosphate-dependent protein kinase? Endocrinology 130 1862-1866

Flores JA, Aguirre C, Sharma OP and Veldhuis JD (1998) Luteinizing hormone $(\mathrm{LH})$ stimulates both intracellular calcium ion $\left(\left[\mathrm{Ca}^{2+}\right]_{\mathrm{i}}\right)$ mobilization and transmembrane cation influx in single ovarian (granulosa) cells: recruitment as a cellular mechanism of $\mathrm{LH}-\left[\mathrm{Ca}^{2+}\right]_{\mathrm{i}}$ dose response Endocrinology 139 3606-3612

Forrester T (1990) Release of ATP from heart: presentation of a release model using human erythrocytes Annals of the New York Academy of Science 603 335-352

Fredholm BB, Abbracchio MP, Burnstock G, Daly JW, Harden TK, Jacobson KA, Leff $\mathbf{P}$ and Williams $\mathbf{M}$ (1994) Nomenclature and classification of purinoceptors Pharmacological Reviews 46 143-156

Fulton BP and Whittingham DG (1978) Activation of mammalian oocytes by intracellular injection of calcium Nature 273 149-151

Gordon JL (1986) Extracellular ATP: effects, sources and fate Biochemical Journal 233 309-319

Goren S, Oron Y and Dekel N (1990) Rat oocyte maturation: role of calcium in hormone action Molecular and Cellular Endocrinology 72 131-138

Gudermann T, Birnbaumer M and Birnbaumer L (1992) Evidence for dual coupling of the murine luteinizing hormone receptor to adenylyl cyclase and phosphoinositide breakdown and $\mathrm{Ca}^{2+}$ mobilization. Studies with the cloned murine luteinizing hormone receptor expressed in L cells Journal of Biological Chemistry 267 4479-4488

Homa ST (1995) Calcium and meiotic maturation of the mammalian oocyte Molecular Reproduction and Development 40 122-134

Homa ST, Carroll J and Swann K (1993) The role of calcium in mammalian oocyte maturation and egg activation Human Reproduction 8 1274-1281

Larsen WJ, Wert SE and Brunner GD (1986) A dramatic loss of cumulus cell gap junctions is correlated with germinal vesicle breakdown in rat oocytes Developmental Biology 113 517-521

Lee PSN, Squires PE, Buchan AMJ, Yuen BH and Leung PCK (1996) P2-purinoreceptor evoked changes in intracellular calcium oscillations in single isolated human granulosa-lutein cells Endocrinology 137 3756-3761

Mattioli M, Gioia L and Barboni B (1998) Calcium elevation in sheep cumulus-oocyte complexes after luteinising hormone stimulation Molecular Reproduction and Development 50 361-369

Moor RM and Heslop JP (1981) Cyclic AMP in mammalian follicle cells and oocyte during maturation Journal of Experimental Zoology $\mathbf{2 1 6}$ 205-209
Moor RM, Osborn JC, Cran DG and Walters DE (1981) Selective effect of gonadotrophins on cell coupling, nuclear maturation and protein synthesis in mammalian oocytes Journal of Embryology and Experimental Morphology 61 347-365

Morley P, Vanderhyden BC, Tremblay R, Mealing GA, Durkin JP and Whitfield JF (1994) Purinergic receptor-mediated intracellular $\mathrm{Ca}^{2+}$ oscillations in chicken granulosa cells Endocrinology 134 1269-1276

Pesty A, Lefevre B, Kubiak J, Geraud G, Tesarik J and Maro B (1994) Mouse oocyte maturation is affected by lithium via the polyphosphoinositide metabolism and the microtubule network Molecular Reproduction and Development 38 187-199

Pincus G and Enzmann EV (1935) The comparative behaviour of mammalian eggs in vivo and in vitro. Journal of Experimental Medicine 62 655-675

Richards JS (1980) Maturation of ovarian follicles: actions and interactions of pituitary and ovarian hormones on follicular cell differentiation Physiological Reviews 60 51-89

Sadighian JJ, Kearns WG, Waddell BJ and Dimino MJ (1989) Effects of diacylglycerol and inositol trisphosphate on steroidogenesis by ovarian granulosa from pigs Biology of Reproduction 40 294-299

Saez JC, Connor JA, Spray DC and Bennett MV (1989) Hepatocyte gap junctions are permeable to the second messenger, inositol 1,4,5trisphosphate, and to calcium ions Proceedings National Academy of Sciences USA $862708-2712$

Sanchez-Yague J, Hipkin RW and Ascoli M (1993) Biochemical properties of the agonist-induced desensitization of the follicle-stimulating hormone and luteinizing hormone/chorionic gonadotropin-responsive adenylyl cyclase in cells expressing the recombinant gonadotropin receptors Endocrinology 132 1007-1016

Sandberg K, Ji H, lida T and Catt KJ (1992) Intercellular communication between follicular angiotensin receptors and Xenopus laevis oocytes: medication by an inositol 1,4,5-trisphosphate-dependent mechanism Journal of Cell Biology 117 157-167

Segaloff DL and Ascoli M (1993) The lutropin/choriogonadotropin receptor 4 years later Endocrine Reviews 14 324-347

Squires PE, Lee PSN, Yuen BH, Leung PCK and Buchan AMJ (1997) Mechanisms involved in ATP-evoked $\mathrm{Ca}^{2+}$ oscillations in isolated human granulosa-luteal cells Cell Calcium (Edinburgh) 21 365-374

Stefenson A, Owman C, Sjoberg NO, Sporrong B and Walles B (1981) Comparative study of the autonomical innervation of the mammalian ovary, with particular regard to the follicular system Cell and Tissue Research 215 47-62

Tai C-J, Kang SK, Tzeng C-R and Leung PCK (2001) Adenosine triphosphate activates mitogen-activated protein kinase in human granulosa-luteal cells Endocrinology 142 1554-1560

Yoshimura Y, Nakamura Y, Oda T, Ando M, Ubukata Y, Karube M, Koyama $\mathbf{N}$ and Yamada $\mathbf{H}$ (1992) Induction of meiotic maturation of follicleenclosed oocytes of rabbits by a transient increase followed by an abrupt decrease in cyclic AMP concentration Journal of Reproduction and Fertility 95 803-812

Received 9 July 2001.

First decision 5 September 2001.

Accepted 20 September 2001. 